Gulawentah: Jurnal Studi Sosial

Vol. 3, No. 1, Juni 2018, hal: $22-29$

ISSN 2528-6293 (Print); ISSN 2528-6871 (Online)

Tersedia Online: http://e-journal.unipma.ac.id/index.php/gulawentah

\title{
Penerapan Metode Investigasi Kelompok Untuk Meningkatkan Sikap Solidaritas Sosial Dan Keterampilan Komunikasi Siswa Kelas V SDN Selosari 2 Magetan Semester Gasal Tahun Pelajaran 2017/2018
}

\author{
Mamik Setyowati \\ SDN Selosari 2 Kecamatan Magetan, Jl. Monginsidi 11, Kabupaten Magetan 63319, Indonesia \\ Email: mamiksetyowati2009@gmail.com
}

\begin{abstract}
Abstrak
Penelitian ini bertujuan untuk meningkatkan sikap solidaritas sosial dan keterampilan komunikasi siswa kelas V SDN Selosari 2 Magetan Semester Gasal Tahun Pelajaran 2017/2018 dengan menerapkan investigasi kelompok. Ada beberapa penyebab rendahnya sikap solidaritas sosial dan keterampilan komunikasi IPS, diantaranya karena penggunaan mengajar selama ini masih sangat monoton yang didominasi ceramah sehingga aktivitas anak kurang nampak. Maka menjadi suatu tantangan bagi seorang guru untuk senantiasa melakukan inovasi dalam menggunakan mengajar. Subyek penelitian yang digunakan oleh peneliti adalah kelas V SDN Selosari 2 sebanyak 25 anak. Pengumpulan data dalam penelitian ini menggunakan wawancara dan observasi. Dalam Penelitian Tindakan Kelas ini peneliti bekerja sama dengan salah seorang guru sebagai kolaborator sekaligus observer dalam mengamati aktivitas belajar siswa. Penerapan investasi kelompok dapat meningkatkan keterampilan komunikasi dan sikap solidaritas siswa kelas V SDN Selosari 2. Aspek keterampilan komunikasi terjadi kenaikan pada siklus 2 daripada siklus 1 . Nilai rata-rata pada siklus 1 mencapai 74,5, sedangkan pada siklus 2 naik menjadi 93. Sedangkan aspek sikap solidaritas sosial siswa selama kegiatan belajar mengajar juga mengalami kenaikan. Siklus 1 mendapatkan rata-rata 75,5, sedangkan pada siklus 2 mencapai 90,5.
\end{abstract}

Kata kunci: investigasi kelompok; sikap solidaritas sosial; keterampilan komunikasi.

\section{The Aplication of Group Investigation Method to Increase Students' Solidarity Attitude and Communication Skill of The Fifth Grade in SDN Selosari 2 Magetan}

\begin{abstract}
This research aims to increase students' social solidarity attitude and communication skill of the fifth grade SDN Selosari 2 Magetan by using Group Investigation Learning Method. There are some reasons why the students have low social solidarity attitude and communications skill in IPS lesson. One of them is using monotonous learning method. It means that the teacher is active to speak and the students only listen the teacher or teacher centered so most students are passive in learning activities. This is as teachers' challenge to use inovative learning method. Researchsubject used by the researcher isclass V SDN Selosari 2 Magetanthat has 25 students. In collecting data, the researcher interviews and observes the students. In this class action research, researcher does it with one of her friends as colaborator and observer in order that she observes the students' learningactivities. The application of group investigation learningmethod can increase students' social solidarityattitude and communication skill class V SDN Selosari 2 Magetan. In the firts cycle the average mark of communication skill can reach to 74,5then in the second cycle the average mark can be 93. And also in social solidarity attitude, in the first cycle the average mark can reach 75,5 then in the second cycle the average mark can be 90,5.
\end{abstract}

Keywords: group investigation learning method; social solidarity attitude; communication skill.

DOI: 10.25273/gulawentah.v3i1.2827

Copyright $@ 2018$ Universitas PGRI Madiun

All rights reserved. 


\section{Pendahuluan}

Gagasan mengenai peningkatan mutu pendidikan di Indonesia sebenarnya tidak pernah berhenti, terutama sejak berlakunya kurikulum sekolah sejak tahun 1975. Kurikulum tersebut merupakan perbaikan kurikulum berbasis pengetahuan menjadi kurikulum berbasis kognitive. Kemudian pada tahun 1984, orientasi pendidikan yang berbasis kognitive disempurnakan menjadi berbasis keterampilan proses. Pada kurikulum 1994 penerapan pendidikan berbasis proses makin diintensifkan. Selanjutnya pada kurikulum 1999 muncul lagi gagasan pembaharuan dengan diperbaikinya konsep pendidikan berbasis kecakapan hidup dan berbasis kompetensi. Semua perubahan di atas seiring dengan perubahan dan perkembangan paradigma pendidikan serta tetap mengacu pada pencapaian tujuan pendidikan nasional.

Banyak faktor yang dapat mempengaruhi keberhasilan implementasi kurikulum, beberapa faktor tersebut diantaranya menajemen lembaga pendidikan, peran guru, keaktifan siswa, proses belajar pengajar, sarana dan prasarana, penggunaan model dan mengajar dan lain-lain. Ketika kita meninjau aktivitas kelas, maka guru adalah ujung tombak proses belajar mengajar. Seorang guru diharapkan memiliki kompetensi yang cukup sebagai pengelola pembelajaran, mampu menciptakan suasana dan lingkungan belajar yang efektif. Selain itu diharapkan terjadi suasana belajar yang dapat meningkatkan aktivitas, kreativitas, dan keaktifan siswa sebagai subjek belajar.

Pendidikan adalah upaya mengembangkan potensi-potensi manusiawi peserta didik baik potensi fisik potensi cipta, rasa, maupun karsanya, agar potensi itu menjadi nyata dan dapat berfungsi dalam perjalanan hidupnya. Dasar pendidikan adalah cita-cita kemanusiaan universal. Pendidikan bertujuan menyiapkan pribadi dalam keseimbangan, kesatuan. organis, harmonis, dinamis. guna mencapai tujuan hidup kemanusiaan.

Filsafat pendidikan ialah hasil pemikiran dan perenungan secara mendalam samapai akar-akarnya mengenai pendidikan . Landasan filosofi pendidikan adalah seperangkat filosofi yang dijadikan titik tolak dalam pendidikan. Landasan filosofis pendidikan sesungguhnya merupakan suatu sistem gagasan tentang pendidikan dan dedukasi atau dijabarkan dari suatu sistem gagasan filsafat umum yang diajurkan oleh suatu aliran filsafat tertentu. Terdapat hubungan implikasi antara gagasan-gagasan dalam cabang-cabang filsafat umum tehadap gagasan-agasan pendidikan. Landasan filosofis pendidikan tidak berisi konsep-konsep tentang pendidikan apa adanya, melainkan berisi tentang konsep-konsep pendidikan yang seharusnya atau yang dicita-citakan.

Pendidikan IPS seharusnya mampu mendidik siswa yang memiliki kepekaan sosial yang tinggi dimasyarakat, rasa empati terhadap kehidupan sosial dan memiliki jiwa kepedulian di masyarakat. Tidak hanya menyampaikan setumpuk materi secara teori. Yang pada ujungnya hanya melahirkan generasi penghafal teori tapi miskin penerapan. Hakekat IPS adalah mata pelajaran sosial yang bersumber dari berbagai disiplin ilmu sosial, yang mempelajarai aspek kehidupan manusia dan interaksinya dalam masyarakat. Secara normatif pembelajaran IPS yang dilakukan harus menggambarkan norma-norma atau aturan yang digariskan dalam kurikulum pendidikan IPS. Dimana penerapan pembelajaran IPS dilakukan secara terpadu antardisiplin ilmu (ekonomi, geografi, sejarah, antropologi).

Namun dari pengalaman empiris peneliti, saat ini masih banyak guru IPS yang mengajar sekedar menyampaikan materi, tanpa memperhatikan tujuan akhir dari pembelajaran IPS. Guru lebih suka menggunakan ceramah. Sehingga siswa kelihatan pasif, komunikasi hanya satu arah yaitu dari guru ke siswa. Tidak jarang pula guru sekedar memberikan catatan tanpa dibahas. 
Berdasarkan pernyataan diatas, maka semestinya guru dapat memilih dan menggunakan model atau metoda pembelajaran yang lebih relevan. Pertanyaan yang timbul adalah model pembelajaran bagaimanakah yang dapat meningkatkan aktivitas, kreativitas, dan keaktivan anak dalam proses belajar mengajar? tersebut harus mampu membuat komunikasi berlangsung dua arah, meningkatkan penguasaan materi dan meningkatkan prestasi belajar siswa. Hasil pengamatan peneliti sebelum mengadakan penelitian, aktivitas belajar siswa pada mata pelajaran IPS sangat rendah. Sebagian besar siswa nampak kurang memperhatiakn selama mengikuti kegiatan belajar mengajar. Banyak yang berbicara dengan temannya, mengganggu temannya, bermain sendiri, bahkan ada yang tidur.

Demikian juga dilihat dari prestasi siswa juga rendah. Dari KKM yang ditentukan sebesar 75, dari 25 siswa hanya 3 anak yang tuntas. Artinya hanya $12 \%$ yang tuntas, sedang $88 \%$ siswa belum tuntas. Ketuntasan belajar klasikal sebesar $12 \%$ ini masih sangat jauh dari yang ditentukan peneliti, dimana peneliti menentukan ketuntasan belajar secara klasikal sebesar $85 \%$. Sementara kalau dilihat dari aspek yang diteliti yaitu aspek keterampilan sosial masih sangat kurang. Hal ini bisa dilihat dari aktivitas siswa masih belajar untuk dirinya sendiri, tidak nampak kerja sama antarsiswa, masih egois dan ingin menang sendiri. Sedang aspek keterampilan komunikasi juga masih kurang. Siswa kurang berani mengemukakan pendapat, kurang menghargai pendapat orang lain. Sehingga hal ini perlu ditingkatkan.

Investigasi kelompok merupakan model pembelajaran kooperatif yang paling kompleks dan paling sulit untuk diterapkan. Model ini dikembangakan pertama kali oleh Thelan. Dalam perkembangan model ini diperluas dan dipertajam oleh Sharan. Berbeda dengan STAD dan Jigsaw, siswa terlibat dalam perencanaan baik topik yang dipelajari dan bagaimana jalannya penyelidikan mereka. Pendekatan ini memerlukan norma dan struktur kelas yang lebih rumit daripada pendekatan yang lebih berpusat pada guru. Pendekatan ini juga memerlukan mengajar siswa keterampilan komunikasi dan proses kelompok yang baik (Trianto, 2009: 78).

investigasi kelompok berorientasi pada pengembangan pribadi untuk berhubungan dengan orang lain, berperan aktif dalam proses demokrasi, dan bekerja produktif dalam kelompoknya. Peran guru dalam investigasi kelompok adalah sebagai konselor, pembimbing dan pemberi saran/kritik yang sahabat. Dalam Group Investigasi, siswa diberi kontrol dan pilihan penuh untuk merencanakan apa yang ingin dipelajari dan diinvestigasikan (Huda, 2013:123).

Belajar kooperatif dengan Grop Investigasi (GI) sangat cocok untuk bidang kajian yang memerlukan kegiatan studi proyek terintegrasi (Slavin, 1995), yang mengarah pada kegiatan perolehan, analisis dan sintesis informasi dalam upaya untuk memecahkan suatu masalah. Oleh karenanya, kesusksesan implementasi teknik kooperatif GI sangat tergantung dari pelatihan awal dalam penguasaan keterampilan komunikasi dan sosial (Rusman, 2013: 221).

Pemnbelajaran Kooperatif tipe Investigasi kelompok dapat dipakai guru untuk mengembangkan kratifitas siswa, baik secara perorangan maupun kelompok. Model pembelajaran kooperatif dirancang untuk membantu terjadinya pembagian tanggung jawab ketika siswa mengikuti pembelajaran dan berorientasi menuju pembentukan manusia sosial (Mafune dalam Rusman, 2013:222). Model pembelajaran kooperatif dipandang sebagai proses pembelajaran yang aktif, sebab siswa akan lebih banyak belajar melalui proses pembentukan (contructing) danpenciptaan, kerja dalam kelompok dan 
berbagai pengetahuan serta tanggung jawab individu tetap merupakan kunci keberhasilan pembelajaran.

Asumsi yang digunakan sebagai acuan dalam pengembangan model pembelajaran kooperatif tipe investigasi kelompok yaitu (1) untuk meningkatkan kemampuan kreativitas siswa dapat ditempuh melalui pengembangan proses kreatif menuju suatu kesadaran dan pengembangan alat bantu yang secara eksplisit mendukung kreatifitas, (2) komponen emosional lebih penting daripada intelektual, yang tak rasional lebih pentingdaripada yang rasional dan (3) untuk meningkatkan peluang keberhasilan dalam memecahkan suatu masalah harus lebih dahulu memahami komponen emosional dan irasional (Rusman, 2013: 223). Adapun langkah-langkah model pembelajaran investigasi kelompok dalam pembelajaran sebagai beriut:

a. Identifikasi topik dan mengatur siswa dalam kelompok

Guru menyediakan beberapa sub kompetensi pelajaran secara umum, siswa memilih sub kompetensi tertentu dari beberapa sub kompetensiyang disediakan oleh guru. Kemudian mengatur diri mereka ke dalam kelompok tugas kecil.

b. Merencanakan tugas belajar

Guru dan siswa masing-masing kelompok merencanakan prosedur atau pola belajar tertentu, tugas-tugas dan tujuan pembelajaran yang sesuai dengan sub kompetesnsi yang dipilih dalam tahap satu.

c. Melaksanakan tugas investigasi

Siswa melaksanakan rencana yang telah diformulasikan pada tahap ke dua. Belajar harus melibatkan berbagai aktivitas keterampilan serta mengarahkan siswa kepada jenis informasi yang berbeda.-beda. Guru secara ketat mengikuti perkembangan masing-masing kelompok dan menawarkan bantuan jika diperlukan.

d. Mempersiapkan laporan akhir

Siswa mangenalisis dan mengevaluasi informasi yang diperoleh pada tahap ketiga. Bagaimana informasi tersebut dapat dirangkum dalam penampilan atau sajian yang menarik bagi anggota kelas.

e. Menyajikan laporan akhir

Sebagian atau seluruh kelompok di dalam kelas memberikan presentasi yang menarik atas topik-topik yang dipelajari agar dapat melibatkan seluruh kelas dalam pekerjaan kelompok lain dan memperoleh pandangan yang lebih luas atas topik tersebut.

f. Evaluasi

Guru dan siswa mengevaluasi kontribusi dan sumbangan individu pada kelompoknya. Pada tahap ini guru berperan dalam memberikan penekanan pada setiap individu siswa. Kontribusi dart hasil pekerjaan kelas secara keseluruhan.

Menurut Kamus Besar Bahasa Indonesia pengertian kata solidaritas adalah, sifat (perasaan) solider, sifat satu rasa (senasip), perasaan setia kawan yang pada suatu kelompok anggota wajib memilikinya (Tim Bahasa, 2009:1082). Menurut Kamus Besar Bahasa Indonesia arti kata sosial adalah berkenaan dengan masyarakat, perlu adanya komunikasi dalam usaha menunjang pembangunan, suka memperhatikan kepentingan umum (Tim Bahasa, 2009:1085). Bentuk-bentuk solidaritas sosial menurut Harapan dan Syarwani (2014:57-58) yaitu gotong royong dan kerjasama, 
Keterampilan berkomunikasi bukan merupakan kemampuan yang dibawa sejak lahir juga tidak akan muncul secara tiba-tiba saat orang memerlukannya. Keterampilan tersebut menurut Johnson (dalam Harapan dan Syarwani, 2014: 59) dapat dipelajari atau dilatih dengan cara sebagai berikut:

a. Harus disadari mengapa keterampilan berkomunikasi ini penting dikuasai dan diketahui manfaatnya bagi semua orang, termasuk bagi seorang guru, kepala sekolah dan praktisi pendidikan lainnya.

b. Harus disadari pula arti keterampilan berkomunikasi dan bentuk-bentuk komponen perilaku yang perlu dikuasai untuk mewuujudkan keterampilan tersebut.

c. Harus rajin mencari atau menemukan situasi-situasi dimana keterampilan tersebut dapat dipraktikan.

d. Tidak boleh segan atau malu meminta bantuan orang lain untuk memantau upaya serta memberikan penilaian tentang kemajuan yang sudah dicapai maupun kekurangan yang harus diperbaiki.

e. Tidak boleh bosan belajar atau berlatih. Keterampilan komunikasi tersebut harus dipraktikan terus menerus.

f. Keseluruhan latihan tersebut dibagi dalam satuan-satuan atau bagian-bagian tertentu, agar dapat dirasakan keberhasilan usaha yang telah dikerjakan.

g. Akan sangat menolong bila dapat menemukan teman yang dapat diajak sebagai lawan berlatih.

h. Keterampilan berkomunikasi dengan seluruh komponen atau bagiannya harus terus menerus dilatih dan dipraktikan sampai akhirnya menjadi bagian yang tidak dapat dipisahkan dari diri seseorang.

\section{Metode Penelitian}

Penelitian dilaksanakan di SDN Selosari 2 Kabupaten Magetan semester gasal tahun pelajaran 2017/2018 semester gasal. Adapun subyek penelitian siswa kelas V yang berjumlah 25 anak. Penelitian ini menggunakan pendekatan kualitatif dengan model penelitian tindakan kelas. Dalam melaksanakan penelitian ini, peneliti berkolaboratif dengan guru kelas V SDN Selosari 2 Magetan. Sedangkan skema penelitian tindakan kelasnya menggunakan sistem siklus seperti pada gambar 1 . 


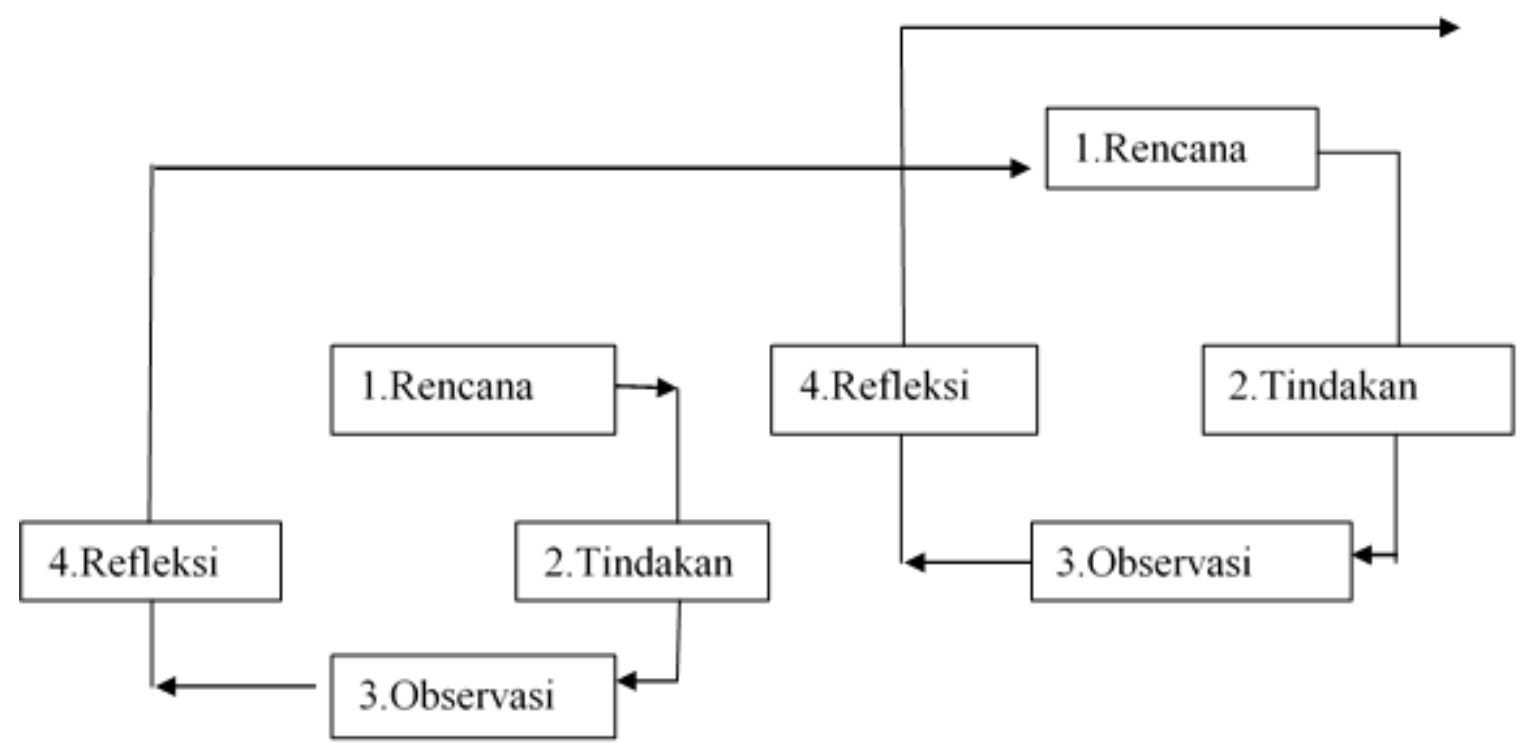

Gambar 1. Skema penelitian tindakan kelas (Mulyasa, 2010:73)

Data penelitian ini dikumpulkan data dengan teknik observasi dan tes. Dari lembar observasi yang sudah dibuat meliputi lembar observasi untuk mengamati keterampilan komunikasi dan lembar observasi untuk mengamati solidaritas sosial. Untuk lembar observasi keterampilan komunikasi aspek yang diamati yaitu penggunaan bahasa yang sopan, pengucapan dan intonasi, dan isi/materi yang disampaikan. Sedangkan aspek solidaritas sosial meliputi : menghargai pendapat orang lain, keaktifan menyampaikan pendapat, dan kerjasama kelompok. Sedangkan data hasil belajar siswa setelah dilakukan koreksi dan scoring akan dianalisa berdasarkan kriteria ketuntasan belajar (mastery learning) yakni $85 \%$ dari jumlah siswa yang telah mencapai $75 \%$ taraf penguasaan materi yang diberikan (KKM 75).

\section{Hasil dan Pembahasan}

\section{Siklus 1}

Setelah mengikuti pembelajaran dengan menggunakan metode GI, keterampilan komunikasi siswa dan solidaritas sosial siswa kelas V SDN Selosari 2 dalam mengikuti kegiatan belajar sebagaimana tercantum dalam tabel 1 .

Tabel 1. Hasil observasi keterampilan komunikasi dan solidaritas siswa pada siklus I

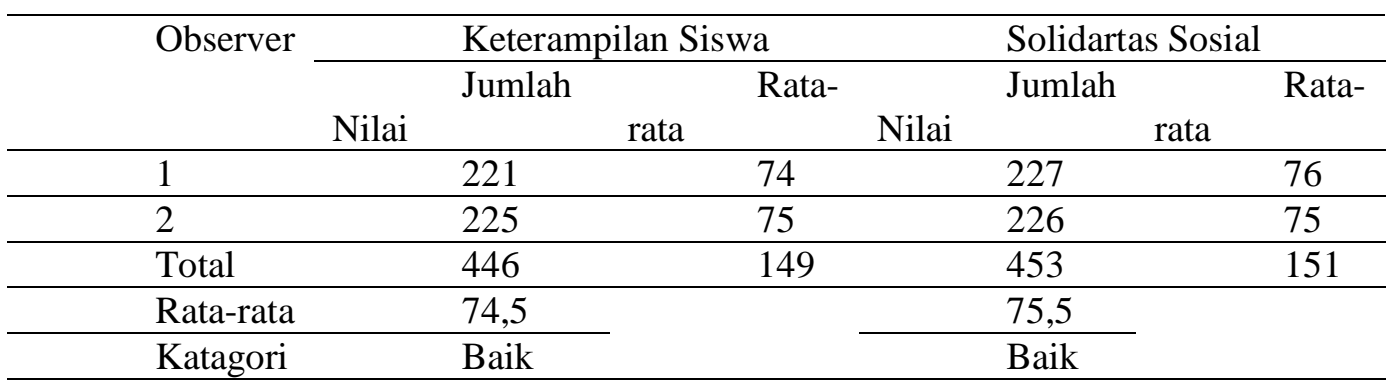

Proses dan hasil pembelajaran pada siklus 1 dapat dianalisis, bahwa selama 70 menit aktivitas belajar siswa yang muncul bervariasi, baik dari aspek keterampilan 
komunikasi maupun sikap solidaritas sosial siswa. Kebanyakan siswa belum banyak melakukan aktivitas pembelajaran yang optimal. Hal ini dapat dilihat pada tabel 2. skor keterampilan komunikasi siswa dan tabel 3. solidaritas siswa.

Tabel 2. Skor keterampilan komunikasi siswa dalam pembelajaran siklus I

\begin{tabular}{cccc}
\hline \multirow{2}{*}{ No } & Kategori Pengamatan & $\begin{array}{c}\text { Skor } \\
\text { Observer 1 }\end{array}$ & $\begin{array}{c}\text { Skor } \\
\text { Observer 2 }\end{array}$ \\
\hline 1 & Penggunaan bahasa yang sopan & 86 & 86 \\
\hline 2 & Pengucapan dan intonasi & 73 & 74 \\
\hline 3 & Isi/materi yang disampaikan & 62 & 65 \\
\hline \multicolumn{2}{c}{ Rata-rata } & 74 & 75 \\
\hline & Rata-rata keseluruhan & 74,5 & \\
\hline
\end{tabular}

Tabel 3. Skor Solidaritas Siswa Dalam Pembelajaran Siklus 1

\begin{tabular}{clcc}
\hline No & \multicolumn{1}{c}{ Kategori Pengamatan } & $\begin{array}{c}\text { Skor } \\
\text { Observer 1 }\end{array}$ & $\begin{array}{c}\text { Skor } \\
\text { Observer 2 }\end{array}$ \\
\hline 1 & Menghargai pendapat orang lain & 86 & 86 \\
\hline 2 & Aktif menyampaikan pendapat & 76 & 75 \\
\hline 3 & Kerja sama dalam kelompok & 65 & 65 \\
\hline$\quad$ Rata-rata & 76 & 75 \\
\hline$\quad$ Rata-rata keseluruhan & \multicolumn{3}{c}{75,5} \\
\hline
\end{tabular}

Melihat data di atas dapat diketahui bahwa: 1) keberanian mengemukakan ide dalam memecahkan masalah dan keberanian dalam kegiatan belajar mengajar masih kurang baik. Terlihat siswa masih enggan dan sering udur-uduran. 2) Siswa masih miskin ide yang diperlukan untuk improfisasi dalam KBM. 3) Walaupun komunikasi antar siswa sudah dapat dibangun, namun demikian masih terlihat siswa yang lain belum antusias dalam pelajaran, terlihat ada beberapa siswa yang mengganggu dan bermain-main sendiri. 4) Karena keterbatasan waktu belum semua hasil pekerjaan siswa dikoreksi. Secara umum keaktifan siswa maupun perhatian terhadap penjelasan guru baik lisan maupun tertulis termasuk kategori baik.

\section{Siklus II}

Setelah berakhirnya pembelajaran pada siklus 1 , sesuai dengan hasil refleksi untuk menyempurnakan kekurangan pada siklus 1, maka pada siklus 2 dilakukan perubahan dan penyempurnaan kegiatan. Adapun hasilnya sebagai berikut:

Tabel 4. Hasil Observasi Keterampilan Komunikasi dan Solidaritas Siswa Pada Siklus 2

\begin{tabular}{ccccc}
\hline \multirow{2}{*}{ Observer } & \multicolumn{2}{c}{ Keterampilan Siswa } & \multicolumn{2}{c}{ Solidartas Sosial } \\
\cline { 2 - 5 } & Jumlah Nilai & Rata-rata & Jumlah Nilai & Rata-rata \\
\hline 1 & 280 & 93 & 272 & 91 \\
\hline 2 & 278 & 93 & 270 & 90 \\
\hline Total & 558 & 186 & 542 & 181 \\
\hline Rata-rata & 93 & & & 90,5 \\
\hline Katagori & Baik & & Baik & \\
\hline
\end{tabular}


Berdasarkan tabel di atas, diketahui bahwa berdasarkan hasil observasi observer 1 dan observer 2. Proses dan hasil pembelajaran pada siklus 2 dapat dianalisis, bahwa selama 70 menit aktivitas belajar siswa nilai yang muncul sudah menunjukkan perkembangan semakin baik kalau dibandingkan dengan siklus 1, baik dari aspek keterampilan komunikasi maupun sikap solidaritas sosial siswa. Hal tersebut dapat dilihat pada tabel 5 dan tabel 6.

Tabel 5. Skor Keterampilan Komunikasi Siswa Dalam Pembelajaran Siklus 2

\begin{tabular}{clcc}
\hline No & Kategori Pengamatan & $\begin{array}{c}\text { Skor } \\
\text { Observer 1 }\end{array}$ & $\begin{array}{c}\text { Skor } \\
\text { Observer 2 }\end{array}$ \\
\hline 1 & Penggunaan bahasa yang sopan & 100 & 98 \\
\hline 2 & Pengucapan dan intonasi & 96 & 90 \\
\hline 3 & Isi/materi yang disampaikan & 84 & 90 \\
\hline$\quad$ Rata-rata & 93 & 93 \\
\hline \multicolumn{2}{c}{93} \\
\hline
\end{tabular}

Tabel 6. Hasil Observasi Keterampilan Komunikasi dan Solidaritas Siswa Pada Siklus 2

\begin{tabular}{cccc}
\hline No & Kategori Pengamatan & $\begin{array}{c}\text { Skor } \\
\text { Observer 1 }\end{array}$ & $\begin{array}{c}\text { Skor } \\
\text { Observer 2 }\end{array}$ \\
\hline 1 & Menghargai pendapat orang lain & 97 & 97 \\
\hline 2 & Aktif menyampaikan pendapat & 91 & 91 \\
\hline 3 & Kerja sama dalam kelompok & 84 & 82 \\
\hline \multicolumn{2}{c}{ Rata-rata } & 91 & 90 \\
\hline & Rata-rata keseluruhan & 90,5 & \\
\hline
\end{tabular}

Melihat data diatas dapat diketahui bahwa: 1) keberanian mengemukakan ide dalam memecahkan masalah dan keberanian dalam kegiatan belajar mengajar sangat baik. 2) Siswa sudah muncul ide yang diperlukan untuk improfisasi dalam KBM. 3) Komunikasi antar siswa sudah dapat dibangun. 4) Secara umum keaktifan siswa maupun perhatian terhadap penjelasan guru baik lisan maupun tertulis termasuk kategori sangat baik.

Pada pembelajaran siklus 1 secara klasikal menunjukan ketuntasan sebesar 32\%. Ini berarti secara klasikal belum tuntas. Hal ini sangat mungkin disebabkan aktivitas belajar siswa yang kurang optimal. Untuk mengatasi permasalahan tersebut diatas, maka peneliti berusaha memperbaiki, menambah dan merubah kegiatan sebagai berikut:

1. Memberikan penjelasan yang lebih detail kepada siswa tentang kegiatan yang harus dilakukan selama kegiatan belajar mengajar.

2. Guru lebih berhati-hati dalam pengelolaan waktu, agar kegiatan belajar selama 70 menit dapat efektif dan setiap kelompok berhasil melakukan investigasi kelompok.

3. Memberikan rangsangan kepada siswa berupa hadiah bagi siswa yang berhasil dalam menyelesaikan tugas.

4. Memberikan motivasi kepada siswa untuk lebih berani berkomunikasi dalam kerja kelompok.

Pada pembelajaran siklus 2 menunjukkan perkembangan yang lebih baik apabila dibandingkan dengan pembelajaran siklus1. Aspek keterampilan komunikasi terjadi 
kenaikan pada siklus 2 daripada siklus 1 . Nilai rata-rata pada siklus 1 mencapai 74,5, sedangkan pada siklus 2 naik menjadi 93. Sedangkan aspek sikap solidaritas sosial siswa selama kegiatan belajar mengajar juga mengalami kenaikan. Siklus 1 mendapatkan ratarata 75,5, sedangkan pada siklus 2 mencapai 90,5.

\section{Kesimpulan}

Berdasarkan hasil pengamatan aktivitas dan perolehan hasil belajar siswa selama 2 siklus, diperoleh simpulan sebagai berikut :Penerapan investasi kelompok dapat meningkatkan keterampilan komunikasi dan sikap solidaritas siswa kelas V SDN Selosari 2.Aspek keterampilan komunikasi terjadi kenaikan pada siklus 2 daripada siklus 1. Nilai rata-rata pada siklus 1 mencapai 74,5, sedangkan pada siklus 2 naik menjadi 93. Sedangkan aspek sikap solidaritas sosial siswa selama kegiatan belajar mengajar juga mengalami kenaikan. Siklus 1 mendapatkan rata-rata 75,5, sedangkan pada siklus 2 mencapai 90,5.

\section{Daftar Pustaka}

Harapan, E. dan Syarwani, A. (2014). Komunikasi Antarpribadi. Jakarta: PT Raja Grafindo Persada.

Huda, M. (2013). Cooperative Learning , Tehnik, Strukturdan Model Terapan. Yogyakarta: Pustaka Pelajar.

Huda, M. (2016). Model-Model Pengajaran dan Pembelajaran. Yogyakarta: Pustaka Pelajar.

Mulyasa.2010. Praktik Penelitian Tindakan Kelas. Bandung: PT Remaja Rosdakarya.

Rusman. (2013). Model-Model Pembelajaran: Mengembangkan Profesionalisme Guru. Jakarta: Rajawali.

Tim Bahasa Depdikbud. (2009). Kamus Besar Bahasa Indonesia. Jakarta: Balai Pustaka.

Trianto. (2009). Mendesain Model Pembelajaran Inovatif Progresif: Konsep, Landasan, dan Implementasinya Pada Kurikulum Tingkat Satuan Pendidikan. Jakarta: Kencana Prenada Media Grop.

Zainal, A. (2013). Model-Model, Media, dan Strategi Pembelajaran Kontekstual (Inovatif). Bandung: CV Yrama Widya. 